2020, Volume 10, International Conference Globalization, Innovation and Development. Trends and Prospects (G.I.D.T.P.), pages: 191-199|

https://doi.org/10.18662/lumproc/gidtp2018/22

\section{Green Accounting - Pivot of Non-Financial Reporting}

\section{Sorina Geanina STĂNESCU ${ }^{1}$, Constantin Aurelian \\ IONESCU ${ }^{2}$, Mihaela Denisa COMAN* $*^{3}$}

${ }^{1}$ Valahia University of Targoviste, Institute of Multidisciplinary Research for Science and Technology, Targoviste, Romania, geaninastanescu@yahoo.com

2 Faculty of Economics, Hyperion University of Bucharest, Bucharest, Romania, ionescuaurelian89@gmail.com

${ }^{3}$ Valahia University of Targoviste, Institute of Multidisciplinary Research for Science and Technology,

Targoviste, Romania, cmndenisa@yahoo.com Corresponding author
Abstract: Lately we talk often about an expansion of financial reporting through the integration of environmental information in the financial statements. Environmental issues become essential for many companies and lots are becoming to include these aspects in their financial reports. Recognizing, evaluating and presenting these issues are the responsibility of management. Thus, is developed a new form of accounting - green accounting, or environmental accounting, as a link for the interaction between the environment and the economy. The objective principal of this research is to present the role that green accounting plays in developing non-financial reporting by identifying and assessing environmental costs and integrating them into reports published by economic entities. After Romania joined the European Union use and implementation the green accounting by national enterprises is increasingly evident. Environmental accounting or green accounting is as a necessary tool for substantiating decisions, is a system used to organize, manage and provide data and information for environment. We initiate the present scientific approach with a theoretical research in order to identify the main stages of the occurrence and the evolution of the environmental accounting. In the final part, we will present the involvement of international accounting organizations in the publication of environmental information, promoting the environmental balance as a form of publication the environmental information in international level.

Keywords: accounting; environment; reports; costs.

How to cite: Stănescu, S.G., Ionescu, C.A., \& Coman, M.D. (2020). Green Accounting - Pivot of Non-Financial

Reporting. In I. Panagoreț \& G. Gorghiu (vol. ed.), Lumen

Proceedings: Vol. 10. International Conference Globalization, Innovation and Development. Trends and Prospects (G.I.D.T.P.) (pp. 191-199). Iasi, Romania: LUMEN Publishing House. https://doi.org/10.18662/lumproc/gidtp2018/22 


\section{Introduction}

Green accounting has been imposed as a necessary tool for substantiating decisions, is a system used to organize, manage and provide environmental information's in physical and value units. It presents an objective picture of the state and change of natural heritage, interactions between the economy and the environment, as well the expenses on prevention, environmental protection and damage to the environment. Economic activity can have negative effects on the production, costs and profit of the enterprise through the effects it causes on the environment, and also on consumer welfare through the changes it causes on the market. Thus, reconsidering the accounting financial system by integrating environmental issues is no longer just an option, but a way to follow by all national and international businesses. Green accounting is considered an important tool for integrating environmental issues into the economy. The information obtained by accounting for environmental costs is essential for sustainable economic development.

In our scientific study we started with a theoretical research, in order to identify the main stages of the occurrence and the evolution of the environmental accounting, in order to highlight the main changes over time of this concept.

Since aspects of the involvement of international accounting organizations in the environmental reporting and the promoting of environmental balance as a form of publication of environmental issues on an international level are of the utmost importance to the majority of economic entities and experts in the fields and require a thorough, in our study we continued with the analysis of these two key issues for environmental accounting.

\section{Theoretical Background}

The concept "green accounting" is first introduced since the 1990s, but the term environmental protection appeared much earlier, in the early 1970s, [11] it presented three distinct periods on the evolution of environmental accounting (1970-1980, 1981-1990, 1991- so far), and later the Romanian researcher Ionel Ienciu [9] continued this evolution. Thus we can present the emergence and development of green accounting in several stages, as follows: Green accounting or environmental accounting, as it is called by many specialists in the field, is not only the integration of environmental costs 
in annual reports [4], it is a system for presenting environmental information's to stakeholders [8], a toll for identifying, analyzing and recording the environmental impact of the economic activity $[12 ; 13]$.

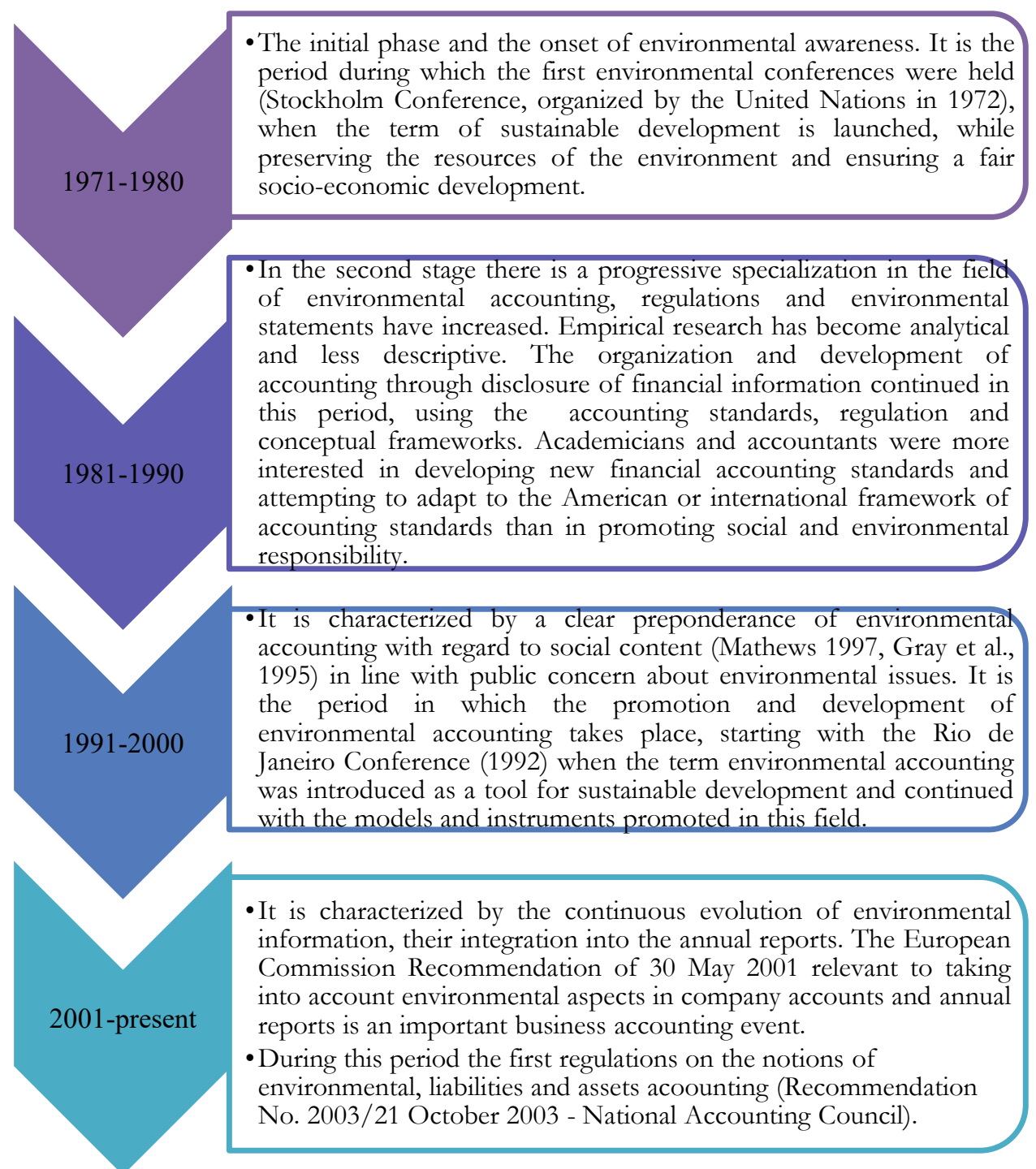

Source: own processing

Figure 1. Evolution of green accounting 
Environmental accounting is used both at microeconomic level to assess costs associated with inventories and natural resource flows, but also at macroeconomic level, by redefining national income. In more works in the field, environmental accounting has been classified according to the environment in which it is used, thus figure 2:

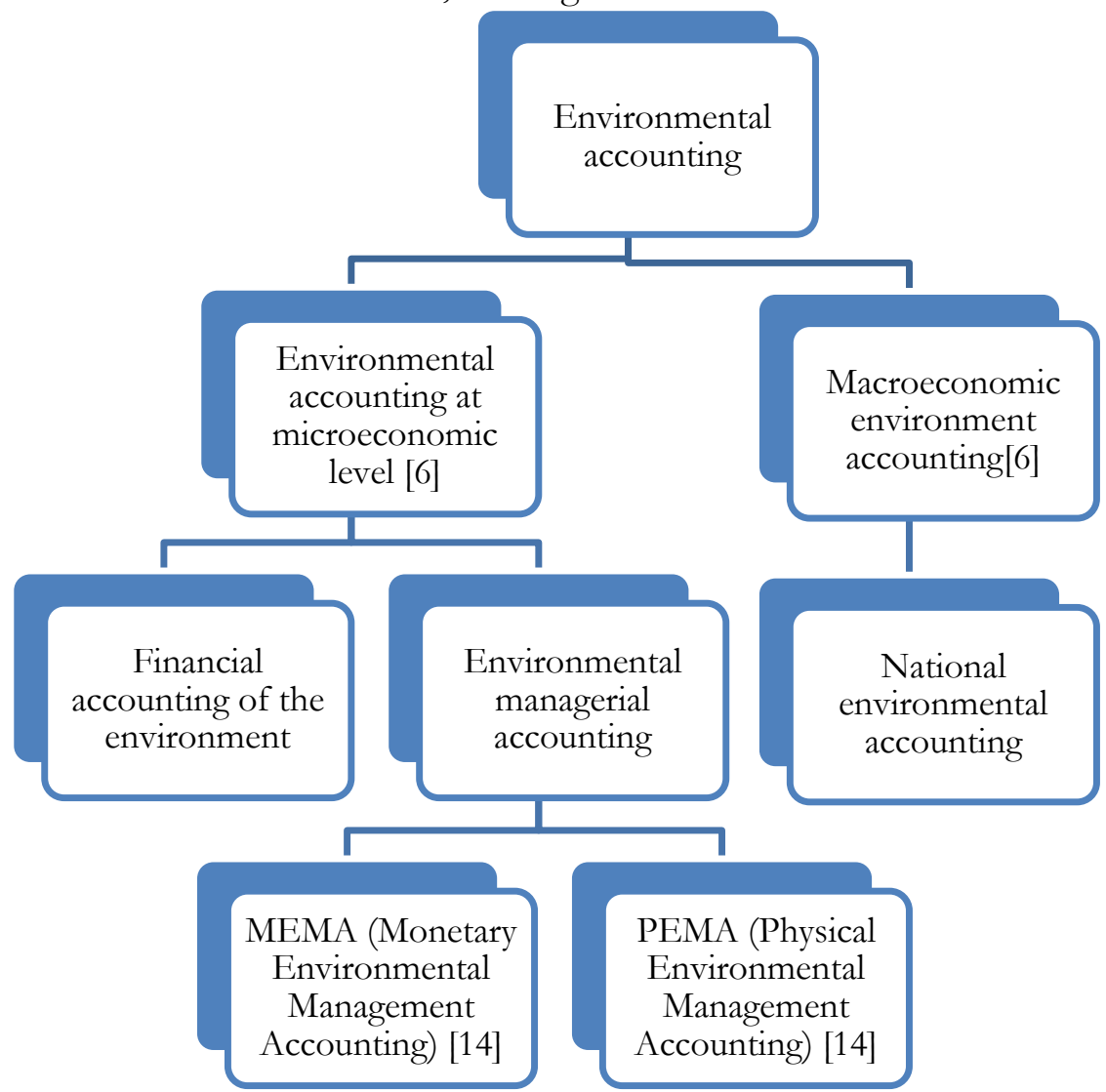

Source: own processing

Figure 2. Clasification of green accounting

Green accounting include all domain of accounting that may be affected by environmental issues, including new areas of eco-accounting [7], and provides objective data on the status and changes of natural heritage, the interaction between the economy and the environment, the costs of preventing damage environment [1]. 


\section{Publication of environmental information in annual reports}

Organizational management pays greater attention to financial results, so the information provided by financial accounting shows the evolution of the enterprise's financial situation over the period under review, usually ignoring environmental issues that do not have strong financial involvement. The publication of environmental information in financial statements is important for stakeholders. Information being environmental risks or environmental costs is the most presented in these reports. But a good sustainable report is important to include aspects of an entity's activity on the economic, social, but also on the environment [2]. The lack of environmental information in the annual reports has been observed by UN experts since the 1980s, which has led to the debate on this issue by different working groups. They have developed studies that show the observed practices and have written guidelines on the presentation of environmental information.

At the international level, based on the recommendations of the IAS / IFRS General Framework, a sustainability report should include information on the overall performance of the organization, as well as the potential risks the organization faces. Also Framework of IAS / IFRS encourages companies whose activity has a significant environmental impact to publish information in an environmental report or sustainability report [3]. At European level through the European Commission Recommendation 2001/453/EC Recommendation on recognition, measurement and disclosure of environmental issues in the annual accounts and annual reports of EU companies it is stated the general framework for presenting environmental information. Thus, the financial statements should contain information on: environmental liabilities, significant environmental costs, as much as possible estimation of environmental expenditure on assets during the year, public aid received for environmental protection. More recently, according to Directive 2014/95 / EU, companies with more than 500 employees have the obligation to draw up the declaration regarding non-financial reporting. By this statement companies can provide much more detailed information on social and environmental issues.

With regard to the presentation of environmental information in the annual financial statements, international bodies have different ways of presenting, so the European Union's Accounting Advisory Forum recommends the use of the profit and loss account for the reporting of environmental expenditures. The European Commission proposes environmental expenditure reporting in the explanatory notes to the 
financial statements proposed also by the IASB and the American Accounting Standards.

\section{Environmental balance sheet - a tool for publication environmental information}

The annual financial reports don't reflect a clear and complete image of the environmental impact of the entity`s activity. Regarding standardization of format publishing reports on environmental information, internationally, were proposed following mechanisms: Global Reporting Initiative Guidelines, Triple bottom line reporting, environmental externalities accounting, and environmental balance sheet [9].

An approach embraced by US companies in particular about the presentation of environmental information is the environmental statement or environmental financial statements. The purpose of the environmental balance is to collect in a single report, annually, all the financial costs and benefits that can be attributed to an enterprise's activities, processes or programs that impact on the environment. Environmental financial statements present a number of new elements to traditional financial statements, such as "savings" (cost reductions from one exercise to another), "cost avoided" (additional costs that have been avoided but would have been borne if environmental impact reduction activities had not taken place) as presented in the table 1.

Table 1. Environmental balance sheet

\begin{tabular}{ll}
\hline \multicolumn{3}{c}{ Estimating environmental costs and savings } \\
\hline \multicolumn{1}{c}{ Reporting period: N-2 N-1 N } \\
\hline Environmental costs \\
\hline Cost of basic programs \\
General costs broken down by division \\
Auditor fees \\
Program to reduce energy consumption \\
Environmental programs \\
Pollution control - operations and maintenance \\
Pollution control - depreciation \\
Total cost of basic programs \\
\hline
\end{tabular}


Estimating environmental costs and savings

Remedial costs

Waste disposal

Environmental taxes and packaging fees

Remedial or restoration costs

Total remedial costs

Total environmental costs

Environmental savings

Reductions in emissions costs

Reductions in the cost of disposing of hazardous waste

Cost reductions for the disposal of hazardous materials

Reduced costs for less hazardous waste disposal

Reduced costs for disposal of less hazardous materials

Recycling earnings

Savings on energy consumption

Reducing packaging costs

Reducing costs for water conservation

Total environmental savings

Summary of environmental savings

Total environmental savings

Costs avoided

Total incomes, savings, costs avoided

Source: Deegan (2006), Financial Accounting Theory [5]

Presenting environmental information in financial statements may be a competitive advantage for businesses with better environmental performance. In terms of factors influencing the decision to report environmental information, they can be classified into three categories [10]: external factors (laws and regulations, legitimacy of the firm, public pressure, public exposure), factors that depend on the organization (organization characteristics, cost/benefit ratio of environmental reporting) and individual factors, such as the culture and attitude of the organization to environmental issues.

\section{Conclusion}

The increasing pressure on organizational management to reduce the impact of economic activity on the environment in order to develop a sustainable economic activity has contributed to the development and implementation of environmental accounting. The traditional approach does not include a full analysis of the environmental impact generated by the economic activity, so environmental accounting is an important step in 
respecting the principles of sustainable development and an instrument in reporting non-financial information.

Environmental information has become significant to a growing number of organizations and has a significant impact on financial statements. We have launched this research with a theoretical approach to the evolution of green accounting over time and the presentation of the main forms of environmental accounting, by stopping us from presenting environmental information in the annual statements of the organization.

International accounting organizations offer more opportunities to report environmental information, most of which are proposed by way of explanatory notes to financial statements. A necessary tool for reporting the environmental information presented in the present research is the environmental balance sheet. This is an instrument that summarizes in one document the environmental information gathered in a detailed and structured manner by the enterprise information system over a year. The environmental balance takes into account the interrelationships between the environment and the enterprise with appropriate indications of the quantitative and qualitative information of the various impacts of productive activities on environmental protection.

\section{References}

[1] Ansamblée parlamentaire, Recomandation 1653. La comptabilité environnementae en tant qu'instrument pour le développement durable. 2004. Available from: http://assembly.coe.int/Documents/AdoptedText/ta04/FREC1653.htm [Accessed 3rd February 2020].

[2] Arnaud P. L'information environnementale: un enjeu à moyen terme pour toutes les enterprises. Revue Francaise de Comptabilité. 2003; 356: 32.

[3] Betianu L. The need to consider environmental information in the annual reports. In: Validation of financial and accounting information in the context of sustainable development. Iasi: Al. I. Cuza University Press Publishing; 2009: 42.

[4] Betianu L. Total quality in environmental accounting. Iaşi: Al. I. Cuza Publishing; 2008: 10.

[5] Deegan C. Financial accounting theory\# 2nd Edition. Australia: McGraw-Hill Australia Pty Limited; 2006: 65.

[6] Graff RG, Reiskin ED, White AL, Bidwell K. Snapshots of environmental cost accounting. A report to US EPA environmental accounting project. Boston, USA: Tellus Institute. 1998 May.

[7] Gray R, Bebbington J. Accounting for the Environment. London:SAGE Publications; 2001 Jul 25: 6.

[8] Gray R, Owen D, Maunders K. Corporate Social reporting: Accounting and Accountability. London: Prentice-Hall; 1987: 4. 
[9] Ienciu IA. Implications of environmental issues in accounting and auditing of financial statements. Cluj-Napoca: Risoprint Publishing; 2009: 67-73.

[10] Lee TM, Hutchison PD. The decision to disclose environmental information: A research review and agenda. Advances in accounting. 2005 Jan 1; 21: 83-111.

[11] Mathews MR. Twenty-five years of social and environmental accounting research: is there a silver jubilee to celebrate? Account Audit Accoun. 1997 Oct 1; 10(4): 481-531.

[12] Mărgărit SG, Bran NC, Relevance of economic instruments used in sustainable development process. Annals of the University of Petroșani. Economics, 2011; 11: 155-166.

[13] Stanescu SG, Cornelia BSN, Nicoleta IE, Ileana-Sorina BR. Coverage of environmental information in annual financial statements in a responsible manner. Procedia-Social and Behavioral Sciences. 2012; 62: 526-530.

[14] United Nations Division for Sustainable Development. Environmental Management Accounting. Procedures and Principles. New York: United Nations; 2001; 8-9. Available from:

http://www.un.org/esa/sustdev/publications/proceduresandprinciples.pdf [Accessed 3rd February 2020]. 